\title{
On Peat Production Capacity in Verkhoyansky District, Sakha (Yakutia) Republic
}

\author{
Vladimir Belyakov ${ }^{1, *}$, and Alexsandra Kuporova ${ }^{1}$ \\ ${ }^{1}$ Tver State Technical University, A. Nikitin Street 22, 170026, Tver, Russia
}

\begin{abstract}
The article analyzes the possible substitution of long-range coal with peat fuel in boilerhouses of Batagai settlement, the Sakha (Yakutia) Republic, and technical and ecological problems that arise. Potential in-situ resources for permafrost production of moulded solid fuel with peat are examined. The study introduces two options of peat fuel production for boilerhouses: peat milling and sod peat moulding. Experimental work on sod peat drying shows that sod peat can be cut and dried to the conditioned moisture content in northern Yakutia but it is inexpedient both technologically and ecologically. A flowsheet of sod peat hydromechanised production from lacustrine peat is presented. According to it peat mass is scarified, diluted with lake water, sucked in by a pump dredge, and then pumped through a sludge line onto the lakeside where it is dehydrated in geotubes to have moulding moisture. Dehydrated geotubes are cut and peat mass is loaded into a peat spreader which stir and shape it into cylindrical peat sods, then spread it on a drying field. Further the process follows the conventional technology of harrowing, ridging, and covering dried peat.
\end{abstract}

\section{Introduction}

Domestic and foreign experts predict that the importance of various biofuels and, first of all, peat will increase. Today some regions of the country use peat [1-4] at the high-tech level as commercial local fuel being competitive with the best imported coal, boiler oil, and sometimes natural gas.

Burning local fuels instead of more qualitative long-range coals is also cost-effective owing to lower transportation and handling costs if a shipment distance is no more than $80 \ldots 100 \mathrm{~km}$ for milled peat and $100 \ldots 150 \mathrm{~km}$ for sod peat.

Verkhoyansky district is in the north-east of the Republic. It is the far north, the Arctic Region where $90 \%$ of the territory is above the Arctic Circle. This involves the definite consequences such as severe climate, the absence of transport and energy infrastructure. One of the main problems [5-7] is the deliveries to the Northern territories of Russia. Verkhoyansky as well as other districts of the Yakutia north-east can live only by the delivered energy resources, food, and manufactured goods [8-9]. Verkhoyansky district has no coal, gas, oil but has peat deposits. At present the territory power engineering entirely depends on long-range coal. Although a large coal deposit Dzhebariki-Khaya in the south of the Republic is relatively not far (in a straight line) from Batagai settlement, the district

\footnotetext{
* Corresponding author: oleg.misnikov@gmail.com
} 
centre, coal has to be delivered in a roundabout way down the Lena and Yana Rivers with port transshipping during two navigation seasons due to geographical conditions (Fig.1). Hereby, the cost of such coal increases dramatically [10]. So the government of the Sakha Republic offered to use peat fuel for Verkhoyansky boilerhouses. According to preliminary estimates peat fuel must be half cheaper than long-range coal.

The task was to evaluate peat deposits of Verkhoyansky district for their production economic feasibility and the possibility of peat use in boilerhouses to supply Batagai district centre with heat.

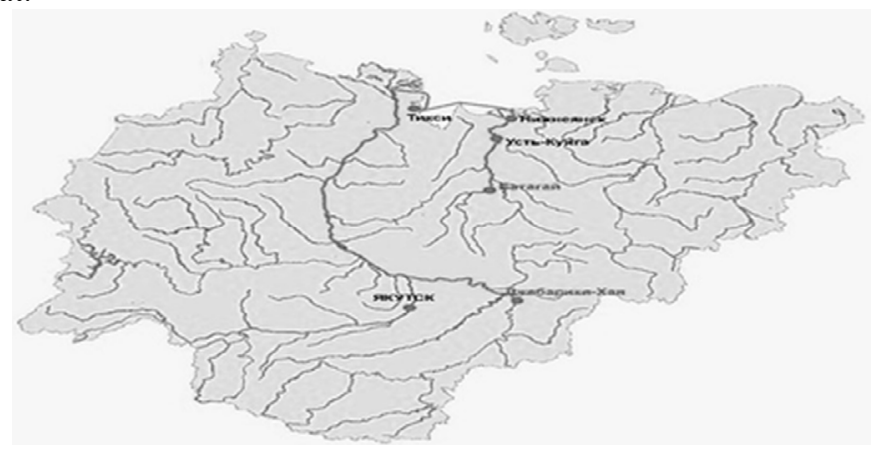

Fig. 1. The route of coal delivery to Batagai settlement.

\section{Materials and Methods}

We introduce two options of producing peat fuel for boilerhouses: milling and peat sod moulding.

Two peat deposits are chosen as in-situ resources of fuel peat for Batagai settlement. Milled peat is to be extracted on the site adjoining Lake Tokolohn. The site area above the permafrost is 100 ha and peat thickness is $0.2 \ldots 0.5 \mathrm{~m}$. The sod peat deposit is under Lake Khotogor not freezing in winter and having air-dried peat reserves of 800,000 t.

To evaluate the possibility of drying milled peat bricks up to the conditioned moisture, they were cut with a special spade (Fig.2) and the following start moisture contents: $80 \%$ in the lakeside zone, $77 \%$ in the middle zone, and $47 \%$ in the hillock zone. Milled peat bricks of any moisture content keep their shape well because of grass roots so they can be loaded onto vehicles and carried to the drying field [11-13]. Drying is carried out in the radiativeconvective conditions on a dry insulating base layer. In precipitation samples are covered under a shelter.

During the period under study (130 hours) the moisture evaporated with an almost constant rate excluding the period when drying was done under a shelter at a relatively low temperature. Within 5 days each damp brick dehydrated for 1.85 to $1.96 \mathrm{~kg}$ of moisture, i.e. half of the water mass to be removed. Within the same period 'dry' sample lost $0.6 \mathrm{~kg}$ of moisture. Thus, the less the moisture content is, the lower the drying rate will be. We can assume that a finished product can be obtained in $15 . .20$ days of field drying in favourable conditions of the air temperature $20 . .30^{\circ} \mathrm{C}$, the presence of wind and the absence of precipitation [14]. 


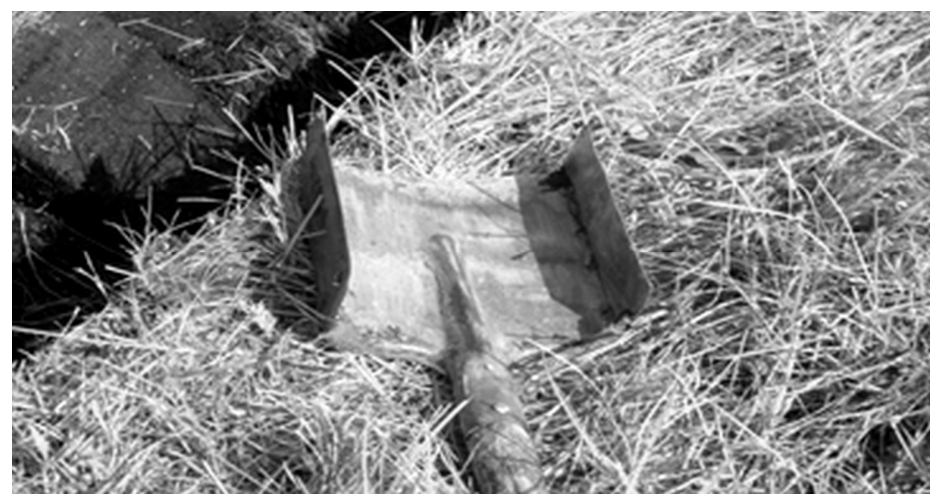

Fig. 2. Spade for cutting peat bricks .

However, rainless spells are quite rare and milled peat, even dried, has high moisture absorption. Therefore, in case of precipitation dried peat must be covered. Peat bricks should be laid in a wave-like way for preliminary drying (Fig. 3).

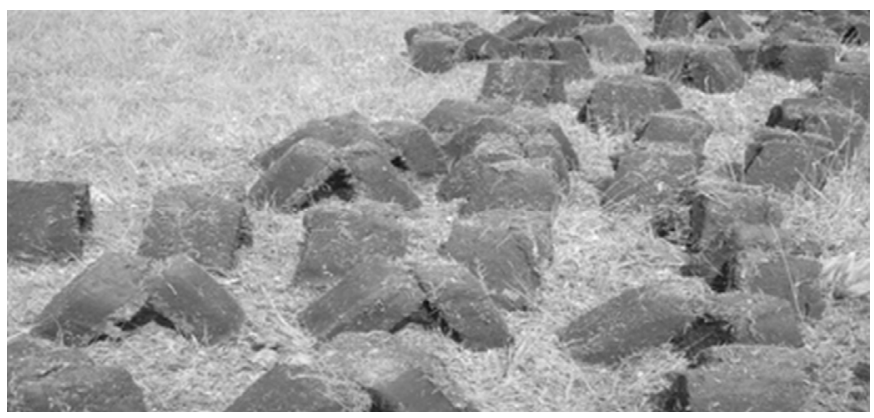

Fig. 3. Laying peat bricks on the drying field.

When dried for approximately two weeks (or longer if it rains or snows) sods should be piled into pyramids of $10 \ldots 15$ layer height under a shelter. The distance between the pyramids is the length of a dried lump $(25 \mathrm{~cm})$. Dry lumps should be piled into lower layers, wet ones - into higher layers. To control moisture content several lumps should be sampled and weighted, marked, and piled for drying with others [15]. When marked lumps lose half of its weight, the whole batch can be stockpiled and compacted.

The approximate time of drying peat in pyramids under a shelter is 30 days before stockpiling. If the all extracted peat can be piled in pyramids under a shelter, it is not necessary to stockpile and compact it.

Experimental works conducted at the end of 1950s in the area of Naryan-Mar town showed that lump peat could be milled. Peat millers can work with a small depth of a thawed layer. Milled bricks (or lumps of different shapes) can be dried in high stockpiles, most of them being elevated above the wet underlying layer. Since there are only shallow deposits in the Batagai area, this technology cannot be used due to insufficient peat layer depth. Peat extraction from lake bottoms is considered to be feasible as the peat layer depth can reach $5 \mathrm{~m}$. The peat does not freeze through under water sheet at $50 \ldots 60{ }^{\circ} \mathrm{C}$ being common for the region. Therefore, peat extraction does not depend on the level of deposit thawing. Suctiontube dredge is proposed to be used. The sludge extracted is transported to the lakeside through a sludge pipeline, dehydrated to the moulding-moisture content, and spread on the drying field with a peat spreader [16]. When dried to the harvesting-moisture content in field 
conditions with some operations to speed up the drying process, peat lumps are put under a shelter where they are dried finally with sublimation if necessary.

\section{Results and Discussion}

A trend for the last 15 years show the application of peat as local fuel in those districts where it was not extracted at all or in small quantities as an experiment. It largely relates to the Far North districts located within the subarctic permafrost zone as well as Kamchatka and Sakhalin. The demand for peat fuel has appeared for many reasons. The main domestic fuel above the Arctic Circle is firewood and long-range coal. The significant part of the Far North is tundra and forest-tundra with either the absence of tree vegetation or its presence in a limited amount (along river valleys mainly). Coal delivery as mentioned earlier increases its costs badly and decreases its quality due to the content of impurities. In that regard municipal utilities have paid attention to peat whose north reserves are huge and located near settlements.

The absence of commercial peat extraction in northern areas is explained by climatic conditions. Summer lasts for $2 \ldots 3$ months (June, July, August). The average temperature of the warmest months (July, August) ranges within $4 \ldots 5^{\circ}$ at the northern border zone and $10 \ldots 12^{\circ}$ at the southern one, with the maximum temperature being from $23^{\circ}$ on the north to $30^{\circ}$ at the south. The annual precipitation in the European tundra makes up about $400 \mathrm{~mm}$, in the East Siberia - 200...250 mm, in the Far East $-300 \ldots 500 \mathrm{~mm}$. The maximum precipitation is in summer. It is cloudy during the whole year. The permafrost zone begins at $40 \ldots 50 \mathrm{~cm}$ depth. Kamchantka and Sakhalin are characterized by marine and wet coast climate, frequent fogs, high air humidity, constant rains, and cold summer. Under these conditions conventional peat extraction used in the central regions of Russia is difficult or just impossible.

However, experimental works conducted in the Nenets Autonomous Area and Kamchatka show that peat extraction is possible there if the climate peculiarities are taken into account and adjusted to.

Milling Batagai's shallow deposit peat is considered to be infeasible since it can be extracted only once and large areas are left damaged for years to come (Fig. 4).

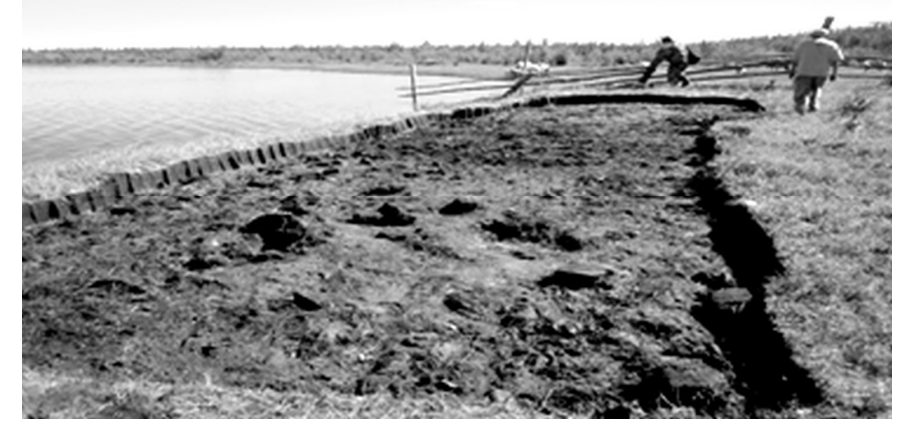

Fig.4. Site of peat milling at Lake Tokolohn.

The production of sod peat from the reserves of Lake Khotogor near-bottom layer can be similar to that of sapropel. In general the production technology of peat-based moulded solid fuel consists in hydraulicking peat sludge with a suction-tube dredge and settling it. Then peat mass of $75 \ldots 80 \%$ moisture content is transported to the place where it is shaped and spread for drying with a pull-type peat spreader. But there are some problems in the conditions of the arctic Yakutia. The first one is the delivery of a suction-tube dredge to the lake. Though there are mini knock-down suction-tube dredges (e.g. GT- 400 EZh) they can 
be delivered by a road only. Therefore, a pontoon single-bucket excavator with a dredge pump is proposed to be used as a dredger (Fig. 5).

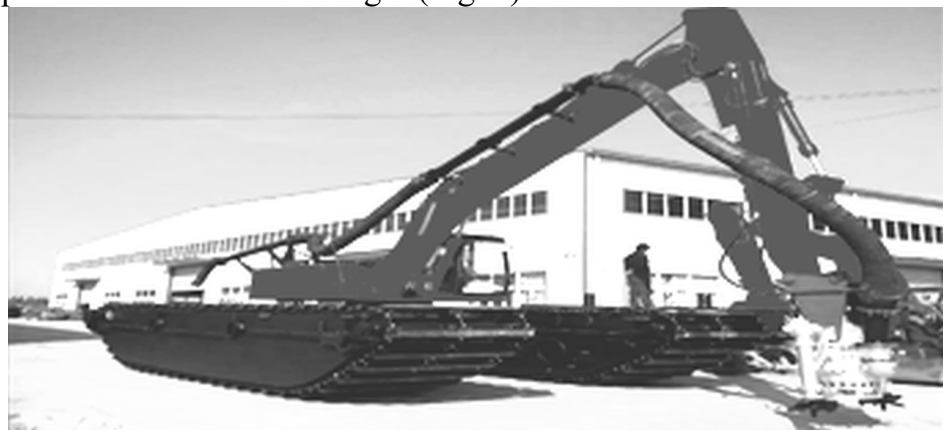

Fig.5. Swampking pontoon excavator with a dredge pump.

The second problem is the sludge pit construction. The conventional technology of the sapropel extraction requires grassy turf to be removed completely on the pit territory. Dike foundations are buried $0.2 \mathrm{~m}$ lower than a pit bottom. Dikes are filled with obligatory compaction by bulldozers or excavators. There is no possibility to fill protruding dikes around Lake Khotogor due to the permafrost layer under $0.5 \mathrm{~m}$ depth and the upper peat layer of 0.5 $\mathrm{m}$ thickness. Therefore, pit walls have to be made of some structural materials, the most available one being larch. In Verkhoyansky district of Yakutia frosts of $40 \ldots 50{ }^{\circ} \mathrm{C}$ settles in November and lasts till May. In some years they can reach more than $60{ }^{\circ} \mathrm{C}$ which results in the complete freezing of peat in pits. If special measures are not taken, it is unlikely to thaw during the following summer. Under these circumstances the method of settling peat in pits can be considered impossible, with the method of rotary drum filters BFA of the Astrakhan sapropel center being an acceptable alternative. But this pattern requires powerful energy generating units to drive electric motors. The better method is to use geotubes sewn from woven fabric of geotextile (Fig.6).

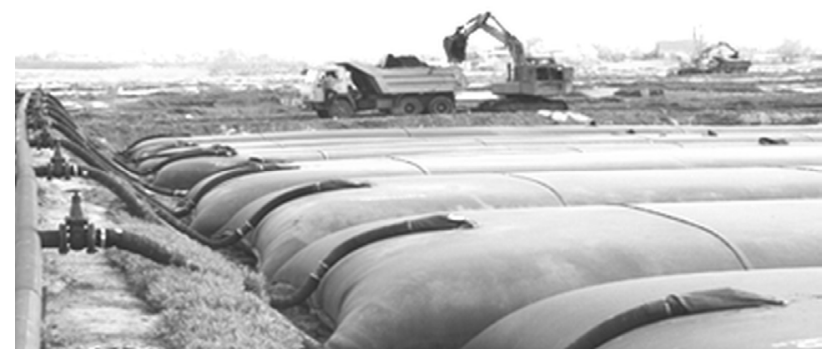

Fig. 6. Geotubes in working condition

The pressure inside a geotube pushes free moisture out and geotextile having special structure retains small sludge particles. Geotubes are produced in a wide range of widths and lengths. Based on the data of sapropel extraction the sludge dehydration in a geotube lasts 20 days up to the moisture content of $80 \%$. These values for lake peat show that two dehydration cycles are enough for a prescribed peat extraction volume of 10 ths tons at one site. According to the estimates, spreading geotubes in one layer requires the area of 5 ha which is 10 times less than the area of pits. In addition, geotextile, which was used for dehydration, can be reused in road construction for roadbeds.

\section{Conclusion}


Peat can be milled and dried to the conditioned moisture content in the northern Yakutia conditions. But the absence of a thick deposit layer makes it inexpedient both technologically and ecologically. In case of favourable geological conditions the lake with a thick layer of near-bottom peat can be drained and peat can be milled.

The hydromechanised peat production is considered to be the most effective method for subwater deposit development, with the lake water drain being unnecessary and extraction being done at any occurrence depth. Moreover, the ecological task of purifying the lake from organic and organomineral sediments is solved.

Peat mass is scarified, diluted with lake water, sucked in by a pump dredge, and then pumped through a sludge line onto the lakeside where it is dehydrated in geotubes to have moulding moisture of $80 \ldots 85 \%$. Dehydrated geotubes are cut and peat mass is loaded with a single-bucket excavator or a front-end loader into a peat spreader which stir and shape it into cylindrical peat sods, then spread it in ribbons or scatter. Peat is spread on allocated sites being sufficient in area and relatively even without bushes. If there are no such sites near the lake, peat mass has to be transported by dumpers or tractor trailers to the spreading place. Further the process follows the conventional technology of harrowing, ridging, and putting dried peat under a shelter.

Combining peat extraction, transportation, improvement, and storage in one process flow, having the possibility of developing rather deep deposits make this method essential and indispensable in most cases. Besides, it is fully mechanized, not labour-intensive and economically sound.

\section{References}

1. E. Afanas'iev, S. N. Gamayunov O. S. Misnikov, Colloid Journal, 61:3, 274-279 (1999)

2. O. S. Misnikov, O. V. Dmitriev, V. I. Popov, and E. Yu. Chertkova, Polymer Science. Series D, 9:1, 133-139 (2016)

3. O. S. Misnikov, O. V. Dmitriev, E. Yu. Chertkova, Eurasian Mining. Gornyi Zhurnal, 2:24, 30-34 (2015)

4. O. Misnikov, Polymer Science. Series D, 7:3, 252-259 (2014)

5. O. S. Misnikov, E. Yu. Chertkova, Eurasian Mining. Gornyi Zhurnal, 1:21, 63-68 (2014)

6. O. Misnikov, A. Timofeev, O. Pukhova Polymer Science. Series D, 8:1, 66-74 (2015)

7. O. Misnikov, V. Ivanov, E3S Web of Conf., 15, 01017 (2017)

8. O. S. Misnikov, I. O. Korolev Polymer Science. Series D, 10:3, 255-259 (2017)

9. O. Misnikov, E3S Web of Conf., 21, 01020 (2017)

10. S. N. Gamayunov, O. S. Misnikov, IFZh, 71:2, 233-234 (1998)

11. O. S. Misnikov, A. E. Afanas'iev, Theoretical Foundations of Chemical Engineering, 7:6, 582-589 (2003)

12. V. Lebedev, O. Puhova, E3S Web of Conf., 21, 01023 (2017)

13. V. Lebedev, O. Puhova, E3S Web of Conf., 15, 01018 (2017)

14. E. A. Kremcheev, D. A. Kremcheeva, Indian Journal of Science and Technology, 9:12, 89525, (2016)

15. E. A. Kremcheev, D. O. Nagornov, Ecology, Environment and Conservation, 23:2, 956965 (2017)

16. E. A. Kremcheev, D. O. Nagornov, Life Science Journal, 11:11s, 453-456 (2014) 